\title{
MAIRIL DAN PERKEMBANGAN ORIENTASI SEKSUAL ALUMNI SANTRI PONDOK PESANTREN
}

\author{
Mohammad Fajrul Fikri dan Dr. Amika Wardana \\ Program Studi Pendidikan Sosiologi, Fakultas IImu Sosial, Universitas Negeri Yogyakarta \\ email: fajrulfikri17@gmail.com
}

\begin{abstract}
Abstrak
Penelitian ini bermaksud untuk mengetahui bagaimana mairil yang ada di pesantren dalam mengonstruksi perkembangan orientasi seksual santri ketika berada di pesantren maupun setelah lulus dari pesantren. Penelitian ini menggunakan metode penelitian kualitatif untuk mendeskripsikan mengenai santri yang mairil (mirip gay) yang ada di pesantren. Informan penelitian ini berjumlah sebanyak 8 orang yang dipilih dengan menggunakan teknik snowball sampling yang mana alumni santri merupakan berjenis laki-laki dan pernah berperilaku gay di pesantren. Pengumpulan data dalam penelitian ini dilakukan melalui wawancara. Teknik validitas data menggunakan triangulasi. Teknik analisis data dalam penelitian ini menggunakan analisis model interaktif Miles dan Huberman yaitu mulai dari pengumpulan data, reduksi data, penyajian data, dan penarikan kesimpulan. Hasil penelitian ini menunjukkan bahwa identitas santri yang mairil (mirip gay) di pesantren ini tidak terlahir sebagai seorang gay. Identitas ini dibangun di lingkungan pesantren melalui proses mengenal, memelajari, hingga akhirnya meniru santri lain yang santri yang mairil (mirip gay), yang kemudian memengaruhi bentuk orientasi maupun perilaku seksual santri di pesantren. Santri yang mairil (mirip gay) yang dilakukan oleh santri termanifestasi dalam beragam bentuk hingga dapat dikatakan sebagai perilaku gay yang meliputi mencitul (mencubit pipi), menyipok (mencium pipi/leher), hingga melakukan aktivitas seksual berupa nyempet (menyelipkan alat kelamin ke sela-sela paha). Santri yang mairil (mirip gay) di pesantren merupakan hal yang biasa terjadi, sehingga hal itu tidak berdampak pada kehidupan sosial santri baik saat berada di pesantren maupun setelah keluar dari pesantren, karena apa yang dialami santri merupakan pergeseran orientasi seksual karena adanya perkembangan psikologis dan emosional yang dapat memengaruhi seksualitas, sehingga seseorang dapat berperilaku homoseksual atau heteroseksual dalam kurun waktu tertentu.
\end{abstract}

Kata Kunci: Mairil, Alumni Santri, Pesantren

This research is to find out how the mairil in the pesantren in constructing the development of the sexual orientation of the students while at the pesantren or after graduating from the pesantren. This study used a qualitative research method to describe the mairil (gaylike) santri in the pesantren. The number of informants in this study were 8 people who were selected using the snowball sampling technique in which the alumni of the students were male and had behaved gays in the pesantren. Data collection in this study was carried out through interviews. The data validity technique used triangulation. The data analysis technique in this study used the interactive model analysis by Miles and Huberman, starting from data collection, data reduction, data presentation, and drawing conclusions. The results of this study indicate that the identity of the mairil (gay-like) santri in this pesantren was not born gay. This identity is built in the pesantren environment through the process of knowing, studying, and finally imitating other santri who are mairil (gay-like) santri, which then influences the form of sexual orientation and behavior of the santri in the pesantren. Santri which is mairil (similar to gay) carried out by santris manifests in various forms so that it can be said to be gay behavior which includes pinching (pinching the cheek), squinting (kissing the cheek/neck), to engaging in sexual activity in the form of gluing (tucking the genitals between between thighs). Santri who are mairil (similar to gay) in pesantren are a common occurrence, so that it does not have an impact on the social life of the santri either while at the pesantren or after leaving the pesantren, because what students experience is a shift in sexual orientation due to psychological and emotional development. which can affect sexuality, so that someone can behave homosexual or heterosexual in a certain period of time.

Keywords: Mairil, Santri Alumni, Pesantren 


\section{Pendahuluan}

Penelitian ini bertujuan untuk mengetahui fenomena adanya perilaku homoseksual (gay) yang dilakukan oleh santri di pesantren. Pada penelitian ini, peneliti memfokuskan pada alumnus pondok pesantren yang pernah mengalami atau pernah berperilaku homoseksual (gay) saat berada di pondok pesantren. Dalam kehidupan homoseksual (gay) di pesantren, terdapat istilah Mairil dan Nyempet. Istilah mairil secara umum merupakan rasa kasih sayang yang dilakukan oleh antar santri, namun seringkali juga ditujukan kepada santri junior yang memiliki ciri-ciri fisik putih, tampan, imut, memiliki lesung pipi, dan memiliki wajah seperti baby faceyang cenderung dijadikan pasangan oleh santri senior. Sedangkan istilah nyempet untuk merepresentasikan aktivitas seksual yang dilakukan oleh santri, yang mana hal ini biasa dilakukan oleh santri senior terhadap pasangan mairilnya dengan cara menghimpitkan kelaminnya ke selasela paha santri mairil, dan hal tersebut biasanya dilakukan pada saat malam hari, terutama pada malam jum'at dengan menunggu santri mairiltertidur pulas agar tidak diketahui oleh santri mairil. (Syarifuddin, 2005:25-28). Dalam kamus sosiologi, homoseksual merupakan seseorang yang cenderung mengutamakan orang berjenis kelamin sama sebagai mitra seksualnya (Haryanto, 2012: 85). Definisi lain dari homoseksualitas yakni mengacu pada rasa tertarik secara perasaan (kasih sayang, hubungan emosional) dan atau secara erotik baik secara predominan (lebih menonjol) maupun secara eksklusif tehadap orang yang berjenis kelamin sama, dengan atau tanpa hubungan fisik. (Oetomo, 2003: 24). Homoseksualitas merupakan salah satu bentuk orientasi seksual yang berbeda, tidak menyimpang, serta memiliki kesejajaran dengan orang yang berorientasi heteroseksual (Kadir, 2007: 66).

Di dalam kehidupan pesantren, terutama pesantren salaf di Jawa terdapat fenomena yang telah menjadi tradisi terkait perilaku gay yang dilakukan oleh kalangan santri yang dikenal dengan istiah Mairil dan Nyempet.Istilah mairil secara umum merupakan rasa kasih sayang yang dilakukan oleh antar santri, yang mana hal itu dapat dimanifestasikan kedalam berbagai bentuk perilaku, terutama dalam hal dorongan perilaku seksual yang disebut dengan istilah nyempet (Riyandeska, 2006:3). Selain itu, istilah mairil merupakan perilaku yang dilakukan oleh santri senior yang dikenal dengan sebutan santri warok kepada santri junior yang dikenal dengan sebutan mairil, yang mana hal tersebut dilakukan dengan berlandaskan kasih sayang sebagai upaya uintuk melindungi, memberikan bimbingan belajar dan tolong menolong dalam kehidupan sehari-hari dengan waktu yang relatif lama. (Oetomo, 2003:31). Selain bentuk kasih sayang yang diberikan oleh santri senior kepada santri junior dengan memberikan bimbingan, melindungi, dan tolong 
menolong tersebut, hubungan kasih sayang diantara keduanya tidak jarang juga disertai dengan adanya kontak fisik berupa persetubuhan, dan hal itulah yang kemudian dikenal dengan istilah nyempet. (Oetomo, 2003, 16).

Menurut Foucault (dalam Kali, 2013: 61-62) menjelaskan bahwa seksualitas bukanlah sesuatu yang tidak dapat berubah, asosial, dan historis. Seksualitas bukanlah bersumber pada hormon kejiwaan dan ketetapan hukum Tuhan, karena seksualitas merupakan konstruksi sosial. Hal senada juga diungkapkan oleh Kandowangko (2014), yang menjelaskan bahwa seksualitas seseorang dapat menjadi proses pembentukan identitas seksual, yang mana proses tersebut didapatkan dari proses belajar yang dialami individu dari adanya pengaruh lingkungan (socio cultural), serta terkait dengan internalisasi dan eksternalisasi nilai-nilai diri terhadap lingkungan.

Perilaku Gay yang terjadi di lingkungan pesantren, terutama pesantren salaf di Jawa yang telah berlangsung lama hingga menjadi tradisi ini berlangsung secara turun temurun, artinya apa yang santri baru atau junior alami itu tidak dapat dilepaskan dari pengalaman yang relatif sama seperti yang dialami oleh santri senior sebelumnya serta beberapa santri senior yang terdahulu. Selain itu perilaku ini tidak hanya dilakukan oleh santri senior terhadap santri junior saja, tidak jarang perilaku gay di pesantren juga dilakukan oleh pengurus pesantren maupun guru di pesantren yang masih muda dan belum menikah, bahkanbagi seorang pengurus maupun santri senior, jika ketahuan teman- temannya memiliki pasangan seorang santri mairil tidak merasa malu, justru mereka bangga, sebagaimana dalam seni tradisional di Ponorogo yang mana warok dapat dikatakan memiliki pamor tinggi jika memelihara seorang gemblak, karena warok dan gemblaknya merupakan tradisi yang sarat nilai(Syarifuddin, 2005:26-28).

Pada awalnya, kehidupan homoseksual di Indonesia, khususnya terkait perilaku gay telah ada dan bahkan fenomena tersebut diakui, diterima dan terlembagakan sejak masa lampau dan telah menjadi bagian dari budaya tradisional Nusantara. Kehidupan kaum homoseksual yang semakin berkembang serta adanya pengaruh dari peradaban Barat atau Islam modernis yang membawa isu homophobia, yakni terkait dengan sikap, perasaan, dan tindakan anti homoseksual nampaknya berdampak dan berpengaruh terhadap pergeseran sikap pada masyarakat Indonesia di era modern saat ini. Hal itu dapat dibuktkan dengan maraknya berbagai aksi yang dilakukan di hampir seluruh penjuru dunia, terutama di Indonesia sekitar tahun 2016-2017 terkait gerakan anti LGBT (Lesbi, Gay, Biseksual, dan Transgeder).

Di Indonesia, dalam kurun waktu 
beberapa tahun terakhir ini dihebohkan dengan maraknya pernikahan sesama jenis, hal itu menimbulkan pro kontra dan keresahan bagi sebagian masyarakat yang menganggap hal tersebut merupakan perilaku yang menyimpang. Perilaku- perilaku yang dianggap menyimpang baik dalam kelompok maupun lingkungan sosial bagi sebagian masyarakat akan menimbulkan sikap, reaksi dan sanksi sosial dari masyarakat yang kemudian berdampak pada kaum homoseksual di Indonesia. Dampak yang dialami oleh kaum homoseksual semuanya kembali tergantung pada seberapa tingkat kualitas penyimpagan yang dilakukan. Selain itu, sikap dan reaksi dari masyarakat juga tergantung pada tuntutan-tuntutan yang dikenakan oleh lingkungan sosial. Sikap dan reaksi sosial dari masyarakat terhadap kaum homoseksual berkiatan dengan norma sosial yang berlaku dalam kehidupan masyarakat yang bersifat kompulsif, yakni memaksa (Kartono, 2015:53)

\section{Metode}

Penelitian ini menggunakan metode penelitian kualitatif, yang mana metodeini digunakan untuk meneliti kondisi obyek secara alamiah yakni apa adanya (Sugiyono, 2015:1-2). Dengan memfokuskan penelitian pada alumnus santri yang pernah berperilaku gay di pesantren, maka lokasi penelitian ini dilakukan dibeberapa tempat warung kopi dan cafe di daerah Jombang dan
Yogyakarta yang telah disepakati oleh peneliti dengan informan. Subjek penelitian merupakan sumber data yang dimintai keterangan informasi mengenai topik penelitian (Arikunto, 2016:10). Dalam penelitian ini subjek penelitiannya ialah alumnus santri yang pernah berperilaku Gay di pesantren yang berjumlah 8 orang.

Adapun waktu yang dibutuhkan dalam melaksnakan penelitian dan pengambilan data ini selama tiga bulan. Sumber data utama dalam penelitian kualitatif adalah kata-kata dan tindakan, selebihnya adalah data tambahan seperti dokuen dan lain-lain. (Moleong, 2014:157). Adapun sumber data yang digunakan dalam penelitian ini ialah menggunakan sumber data primer, yakni merupakan alumnus santri yang berperilaku gay saat berada di pesantren. Dalam melakukan penelitian, teknik pengumpulan data merupakan langkah yang paling strategis dalam penelitian karena tujuan utama dari penelitian ialah untuk mendapatkan data. Adapun teknik pengumpulan data yang digunakan dalam penelitian ini ialah wawancara. Dalam proses pelaksanaan wawancara yang telah dilakukan, secara garis besar pertanyaan yang diajukan seputarpada bagaimana proses pembentukan perilaku gay yang pernah dialami oleh alumni santri saat berada di pesantren, Disamping itu, pertanyaan yang diajukan terkait pada bagaimana dampak yang dialami oleh alumni santri ketika berada di 
luar pesantren.

Teknik sampling merupakan proses pemilihan atau penentuan sampel atau contoh (Bungin, 2012:51). Dalam penelitian ini teknik yang akan digunakan ialah teknik snowball sampling. Pada tahap pemilihan sampling, peneliti memilih informan yang notabene sebagai alumnus santri yang pernah berperilaku gay saat di pesantren untuk diidentifikasi awal kemudian dilanjutkan dengan responden lain berdasarkan rekomendasi dari informan pertama untuk dapat memberikan informasi yang relevan kepada peneliti untuk dapat membantu menjawab rumusan masalah.

Dalam penelitian kualitatif, validitas data sangat diperlukan karena validitas merupakan suatu ukuran derajat ketepatan antara data yang terjadi pada objek penelitian dengan data yang dapat dilaporkan oleh peneliti(Sugiyono, 2015:117). Adapun teknik validitas data dalam penelitian ini menggunakan triangulasi, yakni pengecekan data dari sumber dengan berbagai cara dan berbagai waktu (Sugiyono,2015:125). Teknik analisis data yang digunakan dalam penelitian ini adalah teknik analisis data interaktif dari Miles \& Hubberman, yang mana teknik analisis dimulai dari pengumpulan data, reduksi data, penyajian data, dan penarikan kesimpulan.

\section{Hasil dan Pembahasan}

1. Proses Pembentukan Identitas dan

\section{Perilaku Gay di Pesantren}

Dalam penelitian ini, para informan mengungkapkan bahwa pada dasarnya sebelum masuk pesantren mereka tidak berorientasi dan berperilaku homoseksual sama sekali, sebelumnya mereka tidak mengetahui sama sekali terkait mairilan atau nyempet sebagai perilaku gay yang umum terjadi di pesantren tradisional atau salaf. Proses pengenalan orientasi dan identitas dalam berperilaku homoseksual mereka alami karena adanya pengaruh dari lingkungan sosial saat berada di pesantren, dan masing-masing santri memiliki pola pembentukan perilaku homoseksual yang berbeda.Proses pengenalan perilaku gay di pesantren umumnya dialami oleh santri sejak awal mereka mengikuti kegiatan pengenalan santri baru di pesantren, masa ini merupakan masa krusial karena pada kegiatan tersebut santri senior atau pengurus sudah mulai mencari mana saja santri yang dianggap mairil untuk dijadikan pasangan mairilannya dengan menjadi seorang kakak yang dapat mengayomi dan menunjukkan beberapa hal baru, seperti perilaku gay berupa mairilan dan nyempetyang terdapat di pesantren.

Selain itu, proses pengenalan identitas dan perilaku gay di pesantren juga dialami oleh santri melalui pengalaman aktifitas seksual dengan santri senior atau pengurus lainnya yang berperilaku gay, mulai dari sekedar mencubit pipi yang dikenal dengan istilah 
citul, mencium pipi atau cipok, memeluk, meraba hingga melakukan nyempet yakni menyelipkan alat kelamin ke sela-sela diantara kedua paha atau pantat. Sejak kegiatan masa orientasi pengenalan santri baru, mereka yang dianggap sebagai santri mairil mengalami bujukan, rayuan, bahkan rangsangan dari santri senior atau pengurus dengan beragam motif dan alasan, mulai dari dibelikan makanan dan minuman, dicucikan bajunya, hingga dilindungi dari godaan santri lain.

\section{Identifikasi Bentuk Perilaku Gay di} Pesantren

Pada temuan yang kedua ini membahas terkait adanya beberapa hal yang dapat dikategorikan sebagai perbuatan yang dianggap sebagai praktik gay di pesantren. Beberapa tindakan yang masuk dalam kategori praktik gay di pesantren diantaranya adalah:

a. Citul (mencubit pipi)

Citul, dalam dunia pesantren seringkali dimaknai sebagai perbuatan mencubit yang dilakukan oleh santri terhadap santri. Tapi cubitan yang dilakukan bukan cubit sembarangan. Cubitan yang bermakna citul adalah cubitan yang dilakukan bukan berniat untuk menyakiti. Cubitan ini lebih bersifat gemas, dan kasih sayang. Karena cubitannya bukan bermakna menyakiti atau menghukum, cubitannya pun berbeda dengan cubitan yang biasa dilakukan oleh orang yang berniat mencubit untuk menghukum. Perbedaan dasarnya adalah terletak pada jika mencubit untuk menghukum atau menyakiti itu dilakukan dengan keras, sedangkan citul dilakukan dengan lembut. Dalam praktik kehidupan santri di pesantren yang menjadi objek dalam penelitian ini, terdapat beberapa praktik citul yang dilakukan oleh santri. Praktik semacam ini, meskipun tidak terlalu banyak dilakukan, namun juga tidak seberapa sulit untuk ditemui. Karena praktik citul ini seringkali dilakukan secara terang- terangan di depan santri-santri yang lain. Kebanyakan citul dilakukan dimuka umum, karena sebagai ajang hiburan atau tontonan secara bersama.

Selain itu, apa yang dilakukan oleh orang yang mencitul terhadap santri yang dicitul di muka umum juga sekaligus ditujukan untuk menunjukkan kepada santri lain bahwa santri tersebut merupakan santri mairil. Dengan adanya citulan yang diterima oleh seorang santri, biasanya akan segera berkembang di kalangan santri lain tentang kemairilan santri tersebut. Status kemairilan yang disandang oleh santri yang pernah dicitul biasanya akan berkembang seiringan 
dengan semakin seringnya kisah citulan yang dialaminya diceritakan oleh santri- santri lain. Dengan kata lain, semakin sering cerita pencitulan tersebut diulang-ulang di kalangan santri, maka akan semakin kuat pula predikat mairil yang ada pada santri yang pernah dicitul tersebut. Selain cerita yang diulang-ulang, predikat mairil juga akan berkembang semakin kuat seiring dengan semakin seringnya seorang santri dicitul oleh santri senior lainya, sehingga semakin banyak santri yang mencitulnya, semakin kuat predikat kemairilannya.

Mencitul, selain sebagai pengungkapan bahwa santri yang dicitul adalah santri mairil, pencitulan juga berfungsi sebagai legitimasi bahwa santri tersebut merupakan pasangan mairilannya. Sehingga, dengan cara mencitul dimuka umum dapat menjadi peringatan kepada santri lain agar tidak mengganggu santri mairil-nya itu.

b. Nyempet (menggesekkan alat kelamin di pantat atau menyelipkan ke sela- sela paha)

Dalam dunia santri, nyempet seringkali didefinisikan sebagai perbuatan menggesek-nggesekan kemaluan yang dilakukan oleh seorang santri kepada santri lain yang sesama jenis. Sedikit berbeda dengan citul, nyempet seringkali, bahkan mungkin selalu, dilakukan di tempat dan waktu yang sepi. Saat calon pelaku (santri warok) merasa tidak ada, atau setidaknya sangat minim santri yang melihatnya, karena perilaku nyempet ini termasuk dalam kategori perilaku homoseksual (gay) yang bertingkat tinggi, yang mana perilaku ini merupakan aktivitas seksual yang cenderung melibatkan alat kelamin dan cenderung dilakukan pada situasi dan kondisi yang intim. Oleh karena itulah nyempet seringkali terjadi di waktu malam hari, saat kebanyakan santri sedang terlelap tidur. Nyempet juga sering dilakukan dengan cara yang sangat licin dan samar, sehingga, meskipun para santri itu tidur bersama-sama secara lesehan, mereka jarang sekali ada yang menyadari telah terjadi perbuatan nyempet di sekitar mereka.

Pada awalnya, kejadian nyempet bukanlah hal yang dapat diterima oleh santri yang disempet. Namun dengan beberapa alasan, santri yang disempet biasanya pasrah terhadap keadaan tersebut. Salah satu alasan mengapa perbuatan nyempet itu diterima oleh santri mairil adalah karena ia seringkali merasa nyaman memiliki hubungan dengan santri senior. Ada perasaan 
aman dari gangguan santri lain, ada perasaan diayomi dan dilindungi.

c. Cipok (mencium pipi)

Dalam bahasa santri, nyipok adalah perbuatan mencium seseorang di bagian tertentu. Bagian yang dimaksud biasanya adalah leher atau pipi. Perlu dicatat, nyipok, dalam tradisi santri di pesantren seringkali dilakukan bukan atas dasar suka sama suka maupun rela sama rela. Nyipok seringkali terjadi karena satu punya niat sementara yang lain terpaksa. Dalam budaya mairil di pesantren, nyipok seringkali terjadi dengan cepat. Seorang pelaku nyipok(pencipok) seringkali melakukan aksinya dengan cukup cepat, sehingga santri yang dicipok tidak sempat memahami ada yang hendak menyipoknya. Proses serta pelaku nyipok tidak jauh berbeda dengan citul. Sama-sama terjadi dalam waktu yang tidak terduga, dan terkadang dilakukan di tempat keramaian. Sehingga nyipok dapat termasuk dalam kategori homoseksual (gay) bertingkat relatif sama dengan perilaku nyitul, namun sebaliknya, nyipok juga dapat termasuk perilaku homoseksual (gay) yang bertingkat seperti nyempet jika dilakukan dengan disertai kontak fisik yang mengarah pada hal yang intim. Meskipun nyipok di keramaian identik dengan maksud untuk menggoda santri mairil, namun dalam kasus tertentu, nyipok dilakukan bukan dimaksudkan untuk menggoda santri mairil. Terdapat beberapa kasus yang menunjukkan bahwa nyipok dilakukan karena bermaksud untuk menunjukkan kepada santri-santri lain bahwa ia adalah "pemilik" santri mairil yang dicipoknya di muka umum. Namun, nyipok di hadapan banyak santri lain nampaknya tidak selalu menjadi pilihan utama bagi santri penyipok. Dalam berbagai kesempatan yang lain, seorang penyipok biasa memilih tempat dan waktu yang sepi dengan alasan untuk mendapatkan perasan yang lebih intim.

3. Dampak atau Kondisi Santri Pasca Keluar dari Pesantren

Dalam kehidupan pesantren tidak ada aturan secara tertulis serta hukuman yang diberikan bagi santri yang melakukan perilaku nyempet, sehingga hal tersebut tidak terlalu berdampak secara signifikan bagi santri yang melakukan atau mengalaminya. Hampir secara keseluruhan informan mengungkapkan bahwa dampak yang mereka alami saat ketahuan nyempetbiasanya berupa ejekan atau dijadikan sebagai bullyan, meski cenderung mengalami dampak yang relatif negatif saat berada di 
pesantren, namun hal itu tidak sampai menimbulkan permusuhan atau kebencian dikalangan santri. Sedangkan dampak yang dialami oleh santri pasca keluar dari pesantren pada dasarnya juga hampir sama seperti yang dialami santri saat berada di pesantren, yakni tidak ada dampak yang terlalu signifikan. Dalam artian mereka yang telah menjadi alumni relatif mengalami dampak yang cenderung positif, dimana santri yang telah menjadi alumni tidak berperilaku gay lagi karena mereka beranggapan bahwa perilaku tersebut hanya bersifat sementara dan dilakukan di pesantren saja, sehingga dalam hal ini dapat dipahami bahwa dampak yang dialami oleh alumni santri pasca keluar dari pesantren cenderung positif, dan hal ini juga dapat dipahami bahwa alumni santri yang telah keluar dari pesantren mengalami pergeseran pola orientasi seksual yakni dimulai sebagai orang yang memiliki orientasi heteroseksual, kemudian berubah menjadi homoseksual saat di pesantren, dan kemudian berubah lagi ketika telah keluar dan menjadi alumni pesantren.menunjukkan bahwa apa yang dialami oleh santri selain merupakan pergeseran orientasi seksual juga merupakan perkembangan emosi dan psikologis santri. Hal itu senada dengan apa yang dijelaskan oleh seksolog Amerika yang bernama Alfred Charles Kinsey, yang kemudian terkenal dengan istilah skala Kinsey, dimana skala tersebut untuk mengukur orientasi seksual manusia. la menjelaskan bahwa dalam kehidupan individu terdapat perkembangan psikologis dan emosi seseorang yang kemudian dapat memengaruhi kecenderungan seksualitas seseorang, dalam skalanya tersebut Kinsey menjelaskan bahwa terdapat suatu kesinambungan antara kutub heteroseksualitas dengan kutub homoseksualitas, dimana dalam kurun waktu tertentu seorang individu akan mengalami suatu kecenderungan untuk berorientasi dan berperilaku homoseksual kemudian dalam kurun waktu tertentu lainnya juga dapat mengalami perkembangan yang lebih cenderung mengarah untuk menjadi seorang yang heteroseksual.

\section{Simpulan}

Berdasarkan penelitian yang telah dilakukan mengenai fenomena mairil dan dampak perilaku alumni pondok pesantren, dapat diambil beberapa kesimpulan, bahwa di pesantren sebenarnya terdapat perilaku hubungan sesama jenis yang dilakukan oleh antar santri, yang mana perilaku tersebut seringkali mengarah pada hubungan seksual, dan hubungan ini telah berlangsung lama hingga menjadi tradisi turun temurun kepada generasi santri baru atau junior tiap tahunnya melalui berbagai pola proses pengenalan atau 
pembentukan yang beragam. Mulai dari bujuk rayu secara materi, hingga pengalaman seksual. Namun, para santri hanya mengetahui dan memahami bahwa perilaku yang dilakukan di pesantren merupakan perilaku mairilan, bukan sebagai homoseksual (gay). Kemudian baru munculnya istilah homoseksual atau gay memberi gambaran bahwa apa yang dilakukan oleh santri merupakan perilaku yang termasuk ke dalam homoseksual(gay), karena jika merujuk pada definisi homoseksual (gay), perilaku yang dilakukan oleh antar santri sesama jenis yang juga disertai hubungan seksual yang intim menunjukkan bahwa dalam perilaku tersebut terdapat adanya rasa ketertarikan, orientasi, nafsu, serta hasrat secara seksual terhadap santri sesama jenis yang bersifat sementara, karena hanya dilakukan di pesantren saja, sebelum mengalami perubahan atau pergeseran orientasi kembalimenjadi heteroseksual pasca keluar dari pesantren.

\section{Ucapan Terima Kasih}

Terima kasih kepada semua pihak yang telah mendukung penulisan artikel ini. Kami juga mengucapkan terima kasih kepada redaksi Jurnal Dimensia yang telah menerbitkan tulisan ini.
Bugin, B. 2012. Analisis Data Penelitian Kualitatif: Pemahaman Filosofis dan Metodologis ke Arah Penguasaan Model Aplikasi. Jakarta: Rajawali Press.

Haryanto, S. 2012. Spectrum Teori Sosial dari Klasik hingga Postmodern. Yogyakarta: Ar-Ruzz Media.

Kadir, Hatib A. 2007.Tangan Kuasa dalam Kelamin: Telaah Homoseks, Pekerja Seks, dan Seks Bebas di Indoesia. Yogyakarta: INSISTPress.

Kali, A. 2013. Diskursus Seksualitas Michael Foucault. Flores: Ledalero.

Kandowangko, L. 2014. Tesis S2. Tidak Diterbitkan. Universitas Gadjah Mada.

Kartono, K. 2015. Patologi Sosial. Depok: PT Rajagrafindo Persada.

Miles, Mattew B \& A. Michael Hubberman. 2009. Analisis Data Kualitatif. Jakarta: UI Press

Moleong, L.J. 2014. Metodologi Penelitian Kualitatif. Bandung: PT Remaja Rosdakarya

Oetomo, D. 2003. Memberi Suara pada yang Bisu. Yogyakarta: Pustaka Marwa.

Riyandeska, N.A. 2006. Fenomena Mairil dan Nyempet di Pesantren : Pengalaman Mairil dan Nyempet Mantan Santri dan Dampak Psikologisnya. Skripsi S1. Tidak Diterbitkan. Universitas Airlangga.

Soekanto, Soerjono. 2006. Sosiologi Suatu Pengantar. Jakarta: Rajawali Pers

Sugiyono. 2015 .Memahami Penelitian Kualitatif. Bandung : Alfabeta.

Syarifuddin. 2005. Mairl: Sepenggal Kisah Biru di Pesantren. Yogyakarta: P- Idea.

\section{Daftar Pustaka}

Arikunto, S. 2016. Prosedur Penelitian: Suatu Pendekatan Paktik. Jakarta: PT Rineka Cipta 